\title{
PENGARUH PENYERTAAN MODAL DESA DAN SISA HASIL USAHA BUMDES BERSAMA "BANGKIT MANDIRI" TERHADAP PENDAPATAN ASLI DESA DI KECAMATAN NITA
}

\author{
Cicilia Ayu Wulanari Nuwa ${ }^{1}$ dan Kristianus Bai Apelabi ${ }^{2}$ \\ 1,2 Program Studi Manajemen, Fakultas Ekonomi, Universitas \\ Nusa Nipa Maumere
}

Ciciliaayuwulandari@gmail.com

Abstract
This research belongs to the type of causality research, namely research that
wants to find a causal relationship between the variables of Village Equity
Participation and Remaining Profits from BUMDes Joint "Bangkit Mandiri" to
Village Original Income in Nita District. This research also includes a type of
quantitative research in which the researcher first develops a hypothesis. The next
step is tested quantitatively until finally arriving at the final findings in a tested
hypothesis. The results of the F statistical test show that together with the two (2)
independent variables, namely Village Capital Inclusion (X1) and BUMDes
Business Results (X2), have no significant effect on Village Original Income $(Y)$.
The results of the $t$-statistical test show that individually (partial), the Village Capital
Participation Variable $(X 1)$ has no significant effect on the Village Original Income
Variable $(Y)$. This means that if the Equity Participation variable (X1) increases, the
increase in the Equity Participation variable does not increase the Village Original
Income $(Y)$ variable. Meanwhile, the residual income variable for BUMDes $(X 1)$ has
no significant effect on the Village Original Income Variable (Y). This means that if
the BUMDes residual income variable (X2) increases, the increase in the BUMDes
remaining operating income variable does not increase the village original income
variable (Y). Furthermore, the contribution of the two independent variables in this
study which consists of Village Capital Inclusion (X1) and Rest of BUMDes
Business Results (X2), can explain the variation of ups and downs in Village
Original Income (Y) in all villages in Nita District by 1.3\%. At the same time, the
remaining 98.7\% is explained by other variables that are not included in this
research model.
Keywords: village capital inclusion, BUMDes, and village original income.




\section{PENDAHULUAN}

Berdasarkan Undang-Undang Nomor 6 Tahun 2014 pasal 1 ayat (6), menyatakan bahwa Badan Usaha Milik Desa selanjutnya disebut BUMDes merupakan badan usaha yang seluruh atau sebagian besar modalnya dimiliki oleh desa melalui penyertaan langsung yang berasal dari kekayaan desa yang dipisahkan guna mengelola aset, jasa pelayanan, dan usaha lainnya untuk sebesarbesarnya kesejahteraan masyarakat. Dengan berdirinya badan usaha milik desa diharapkan meningkatkan perekonomian masyarakat dan memupuk modal.

BUMDes Bersama Bangkit Mandiri merupakan lembaga usaha yang didirikan berdasarkan kesepakatan desa-desa dalam wilayah Kecamatan Nita, yang dituangkan dalam Peraturan Bersama Para Kepala Desa se Kecamatan Nita. BUMDes Bersama Bangkit Mandiri ini dideklarasikan pada tanggal 21 Juli 2017 yang dituangkan dalam Keputusan Bersama Kepala Desa Nomor 01 tahun 2017. Desa-desa yang dimaksud adalah Desa Nita, Desa Takaplager, Desa Wuliwutik, Desa Tebuk, Desa Tilang, Desa Lusitada, Desa Bloro, Desa Mahebora, Desa Riit, Desa Ladogahar, Desa Nitakloang dan Desa Nirangkliung.

BUMDes Bersama Bangkit Mandiri merupakan lembaga usaha yang didirikan berdasarkan kesepakatan desa-desa dalam wilayah Kecamatan Nita, yang dituangkan dalam Peraturan Bersama Para Kepala Desa se Kecamatan Nita. BUMDes Bersama Bangkit Mandiri ini dideklarasikan pada tanggal 21 Juli 2017 yang dituangkan dalam Keputusan Bersama Kepala Desa Nomor 01 tahun 2017. Desa-desa yang dimaksud adalah Desa Nita, Desa Takaplager, Desa Wuliwutik, Desa Tebuk, Desa Tilang, Desa Lusitada, Desa Bloro, Desa Mahebora, Desa Riit, Desa Ladogahar, Desa Nitakloang dan Desa Nirangkliung.

BUMDes Bersama merupakan pilar kegiatan perekonomian di wilayah desadesa yang berfungsi sebagai lembaga sosial (social institution) dan komersial (commercial institution). Selain berperan sebagai lembaga sosial yang berpihak pada kepentingan masyarakat melalui kontribusinya dalam penyediaan pelayanan sosial, juga sebagai lembaga komersial yang bertujuan mencari keuntungan melalui penawaran sumber daya lokal maupun non lokal ke pasar. Pembentukan BUMDes Bersama ini sesuai dengan PP Nomor 47 tahun 2015, tentang pendirian BUMDes Bersama oleh beberapa desa dengan tujuan untuk memberikan pelayanan usaha antar desa. Setiap desa menyertakan modal ke BUMDes Bersama "Bangkit Mandiri" dalam bentuk uang tunai sesuai dengan kesepakatan dalam Musyawarah Antar Desa.

Yang dimaksud dengan sisa hasil usaha BUMDes (Badan Usaha Milik Desa) adalah pendapatan yang diperoleh dari hasil transaksi dikurangi dengan pengeluaran biaya dan kewajiban pada pihak lain, serta penyusutan atas barangbarang inventaris dalam 1 (satu) tahun buku. Dalam pembagian hasil usaha BUMDes ini ditetapkan berdasarkan ketentuan yang diatur dalam Anggaran Dasar/Anggaran Rumah Tangga Bumdes. Pembagian hasil usaha BUMDes nantinya akan disumbangkan ke Pendapatan Asli Desa (PADes) yaitu atas hasil musyawarah dan kesepakatan antara pihak BUMDes dan pihak desa yang nantinya dengan hasill usaha BUMDes tersebut akan berpengaruh terhadap peningkatan Pendapatan Asli Desa. (UU Nomor 6 Tahun 2014). 
Jumlah pembagian SHU setiap tahun yang dibagikan ke-12 desa mengalami penurunan. Penurunan terjadi di tahun 2019 sebesar Rp. 2.100.000,- (Dua Juta Seratus Ribu Rupiah). Berdasarkan wawancara dengan Bendahara BUMDes Bersama diperoleh keterangan bahwa penurunan SHU ini terjadi karena kekurangan modal dan angka kredit macet yang cendrung meningkat serta biaya operasional yang relatif meningkat pada setiap unit usaha. Berdasarkan penelitian yang dilakukan oleh Justina $\mathrm{H}$. De Fatima, Charles Kapioru dan I Nyoman Sirma tentang Evaluasi Kinerja Keuangan Pada Badan Usaha Milik Desa Bersama "Bangkit Mandiri" Kecamatan Nita Kabupaten Sikka dalam Jurnal Excellentia, volume IX No 2, Desember 2020 yang menganalisis tentang Rasio Likuiditas, Rasio Solfabilitas dan Rasio Rentabilitas selama kurang lebih 3 tahun yaitu tahun 2017 sampai dengan tahun 2019. Hasil perhitungan rasio likuiditas menujukkan bahwa BUMDes Bersama "Bangkit Mandiri" mempunyai kriteria SEHAT dengan hasil perhitungan tahun 2017 sebesar $5,008 \%$, tahun 2018 sebesar $2,559 \%$ dan tahun 2019 sebesar 2,665\%. Tetapi dalam prakteknya, jumlah aktiva lancar yang terlalu besar sehingga terjadi penumpukan aktiva lancar. Jika aktiva lancar ini diinvestasikan maka akan mendatangkan keuntungan. Hasil analisis rasio solvabilitas, BUMDes Bersama "Bangkit Mandiri" masuk dalam kriteria SEHAT dengan hasil perhitungan tahun 2017 sebesar 5,34\%, tahun 2018 sebesar 14,79\% dan tahun 2019 sebesar 15,04\%.. Sedangkan hasil analisis rasio rentabilitas menunjukkan bahwa BUMDes Bersama "Bangkit Mandiri" masuk dalam kriteria TIDAK SEHAT dengan hasi perhitungan tahun 2017 sebesar 1,94\%, tahun 2018 sebesar 1,52\% dan tahun 2019 sebesar 1,74\%. Hal ini berarti kemampuan BUMDes Bersama "Bangkit Mandiri" dalam menghasilkan laba masih berada di bawah standar yang telah ditetapkan.

Sisa Hasil Usaha untuk Pendapatan Asli Desa akan ditransfer ke Rekening Kas Desa (RKD) dan akan digunakan sesuai dengan Dokumen Pelaksanaan Anggaran (DPA) yang sudah disepakati dalam Musyawaran Desa Penetapan APBDes. Dengan demikian, APBDes diharapkan akan mampu mendorong roda perekonomian di tingkat desa, termasuk untuk menjawabi kebutuhan-kebutuhan masyarakat yang mampu ditangani di tingkat desa. APBDes yang memadai juga dapat mendorong partisipasi warga yang lebih luas pada proses-proses perencanaan dan penganggaran pembangunan. Usulan kebutuhan masyarakat yang tidak terakomodir dalam perencanaan APBD, dapat diakomodir melalui APBDes untuk menjawabi kebutuhan yang berskala kecil di tingkat desa (Yabbar dan Hamzah 2015).

Menurut Undang-Undang Nomor 32 Tahun 2004 tentang Pemerintahan Daerah menyebutkan bahwa BUMDes didirikan antara lain dalam rangka meningkatan Pendapatan Asli Desa (PADes). Hal ini berarti, jika Pendapatan Asli Desa dapat diperoleh dari BUMDes, maka kondisi itu akan mendorong setiap Pemerintah Desa memberikan "goodwill" dalam merespon pendirian BUMDes. Sebagai salah satu lembaga ekonomi yang beroperasi di pedesaan, BUMDes harus memiliki perbedaan dengan lembaga ekonomi pada umumnya. Ini dimaksudkan agar keberadaan dan kinerja BUMDes mampu memberikan kontribusi yang signifikan terhadap peningkatan Pendapatan Asli Desa. 
Berdasarkan latar belakang permasalahan dan beberapa penelitian terdahulu maka penulis tertarik untuk melakukan penelitian dengan judul Pengaruh Penyertaan Modal Desa dan Sisa Hasil Usaha BUMDes Bersama "Bangkit Mandiri" Terhadap Pendapatan Asli Desa di Kecamatan Nita.

\section{TINJAUAN PUSTAKA}

\subsection{Badan Usaha Milik Desa (BUMDes)}

BUMDes adalah sebuah lembaga usaha desa yang dikelola oleh pemerintah desa juga masyarakat desa dengan tujuan untuk memperkuat perekonomian desa berdasarkan kebutuhan dan potensi yang ada di desa (Wiratna Sujarweni, 2019:7). Muryani (2008:35) memberikan pengertian mengenai BUMDes sebagai wadah bagi masyarakat dan pemerintah desa untuk memajukan perekonomian berdasarkan potensi dan kebutuhan lokal desa

Menurut PP Nomor 11 Tahun 2021 tentang BUM Desa, BUM Desa adalah badan hukum yang didirikan oleh desa dan / atau bersama desa-desa guna mengelola usaha, memanfaatkan aset, mengembangkan investasi dan produktivitas, menyediakan jasa pelayanan, dan / atau menyediakan jenis usaha lainnya untuk sebesar-besarnya kesejahteraan masyarakat desa.

Dengan demikian dapat disimpulkan bahwa BUMDes adalah badan usaha yang pengelolaannya melibatkan satu desa atau lebih secara bersama-sama dalam mengelola usaha, mengembangkan investasi, menyediakan jasa pelayanan untuk kesejahteraan masyarakat desa. BUMDes menjadi wadah pemersatu desa dan / atau antar desa dalam mengelola potensi potensi ekonomi, sumber daya alam dan sumber daya manusia untuk mencapai kesejahteraan bersama.

\subsection{Penyertaan Modal Desa}

Berdasarkan Undang-Undang Nomor 6 Tahun 2014 pasal 1 ayat (6), menyatakan bahwa Badan Usaha Milik Desa selanjutnya disebut BUMDes merupakan badan usaha yang seluruh atau sebagian besar modalnya dimiliki oleh desa melalui penyertaan langsung yang berasal dari kekayaan desa yang dipisahkan guna mengelola aset, jasa pelayanan, dan usaha lainnya untuk sebesarbesarnya kesejahteraan masyarakat. Dengan berdirinya Badan Usaha Milik Desa diharapkan meningkatkan perekonomian masyarakat dan memupuk modal. Penyertaan modal adalah pengalihan kepemilikan aset milik desa yang semula merupakan kekayaan yang tidak terpishkan menjadi kekayaan yang dipisahkan untuk diperhitungkan sebagai modal atau saham desa pada Badan Usaha Milik Desa (BUMDes). BUMDes berhak mengajukan penyertaan modal selama program dan kegiatan BUMDes masuk dalam Rencana Kerja Pemerintah Desa (RKPDes). Pada tahap inilah penggerak BUMDes maupun pengurus BUMDes harus aktif dan berani menyuarakan aspirasi mereka untuk BUMDes melalui Musyawarah Desa dan/ Musyawarah Antar Desa. Pengurus BUMDes dapat mengajukan program, kegiatan dan anggaran termasuk penyertaan modal selama rencana tersebut dapat dipertanggungjawabkan 


\subsection{Model Penelitian}

Kerangka berpikir merupakan konsep penelitian tentang bagaimana hubungan teori dengan berbagai faktor yang telah didefinisikan sebagai masalah yang akan diteliti.

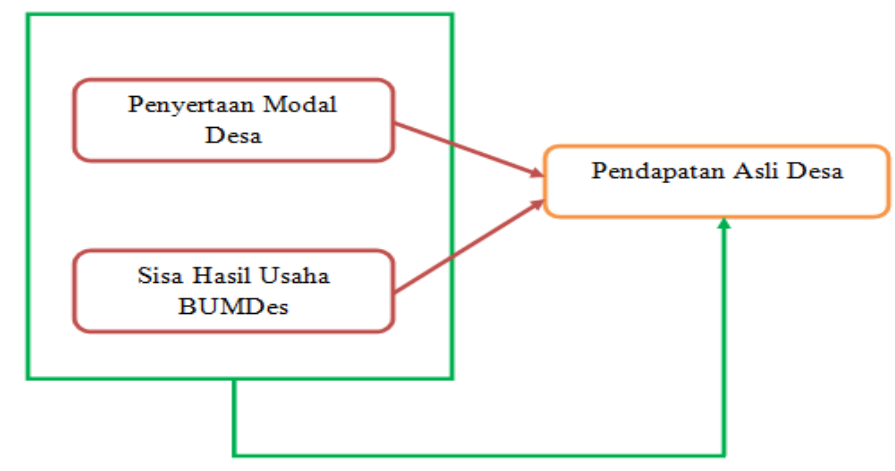

Gambar 1. Model Penelitian

Keterangan:

$\longrightarrow$ : Pengaruh secara parsial

$\longrightarrow \quad$ : Pengaruh secara simultan

\subsection{Pengaruh Penyertaan Modal Desa terhadap Pendapatan Asli Desa}

Berdasarkan Undang-Undang Nomor 6 Tahun 2014 pasal 1 ayat (6), menyatakan bahwa Badan Usaha Milik Desa selanjutnya disebut BUMDes merupakan badan usaha yang seluruh atau sebagian besar modalnya dimiliki oleh desa melalui penyertaan langsung yang berasal dari kekayaan desa yang dipisahkan guna mengelola aset, jasa pelayanan, dan usaha lainnya. Penyertaan modal dari desa ini akan dikelola oleh BUMDes dan hasil keuntungan yang diperoleh dari unit-unit usaha akan memberikan kontribusi bagi Pendapatan Asli Desa (PADes).

Hipotesis 1: Terdapat pengaruh secara parsial dan signifikan antara Penyertaan Modal Desa terhadap Pendapatan Asli Desa.

\subsection{Pengaruh Sisa Hasil Usaha BUMDes Bersama Bangkit Mandiri terhadap Pendapatan Asli Desa \\ Menurut Undang-Undang Nomor 6 tahun 2014, yang dimaksud dengan sisa} hasil usaha BUMDes (Badan Usaha Milik Desa) adalah pendapatan yang diperoleh dari hasil transaksi dikurangi dengan pengeluaran biaya dan kewajiban pada pihak lain, serta penyusutan atas barang-barang inventaris dalam 1 (satu) tahun buku. Dalam pembagian sisa hasil usaha BUMDes ini ditetapkan berdasarkan ketentuan yang diatur dalam Anggaran Dasar/Anggaran Rumah Tangga BUMDes. Pembagian sisa hasil usaha BUMDes nantinya akan disumbangkan ke Pendapatan Asli Desa 
(PADes) yaitu atas hasil musyawarah dan kesepakatan antara pihak BUMDes dan pihak desa yang nantinya dengan sisa hasil usaha BUMDes tersebut akan berpengaruh terhadap peningkatan Pendapatan Asli Desa.

Hipotesis 2 :Terdapat pengaruh secara parsial dan signifikan antara Sisa Hasil Usaha BUMDes Bangkit Mandiri terhadap Pendapatan Asli Desa.

\subsection{Pengaruh Penyertaan Modal Desa dan Sisa Hasil Usaha BUMDes Bersama Bangkit Mandiri terhadap Pendapatan Asli Desa}

Berdasarkan Undang-Undang Nomor 6 Tahun 2014 pasal 1 ayat (6), menyatakan bahwa BUMDes merupakan badan usaha yang seluruh atau sebagian besar modalnya dimiliki oleh desa melalui penyertaan langsung yang berasal dari kekayaan desa yang dipisahkan guna mengelola aset, jasa pelayanan, dan usaha lainnya untuk sebesar-besarnya kesejahteraan masyarakat. Penyertaan modal dari desa ini akan dikelola oleh unit-unit usaha BUMDes. Hasil pendapatan yang diperoleh dari hasil transaksi akan dikurangi dengan pengeluaran biaya dan kewajiban pada pihak lain, serta penyusutan atas barang-barang inventaris dalam 1 (satu) tahun buku. Sisa hasil usaha yang diperoleh selama setahun akan dibagi berdasarkan ketentuan yang diatur dalam Anggaran Dasar/Anggaran Rumah Tangga BUMDes. Sisa hasil usaha BUMDes nantinya akan ditransfer melalui rekening desa untuk meningkatkan Pendapatan Asli Desa (PADes).

Hipotesis 3 :Terdapat pengaruh secara simultan dan signifikan antara Penyertaan Modal Desa dan Sisa Hasil Usaha BUMDes Bangkit Mandiri terhadap Pendapatan Asli Desa.

\section{METODOLOGI PENELITIAN}

Penelitian ini termasuk jenis penelitian kausalitas, yaitu penelitian yang ingin mencari hubungan sebab akibat antar variabel Penyertaan Modal Desa dan Sisa Hasil Usaha BUMDes Bersama "Bangkit Mandiri" terhadap Pendapatan Asli Desa di Kecamatan Nita. Penelitian ini juga termasuk jenis penelitian kuantitatif di mana peneliti terlebih dahulu mengembangkan hipotesis. Penelitian ini dilakukan pada Kantor BUMDes Bersama "Bangkit Mandiri" Kecamatan Nita, Kabupaten Sikka Provinsi Nusa Tenggara Timur. Waktu penelitian dilakukan dari tanggal 16 - 19 Juni 2021. Dalam penelitian ini data diperoleh melalui wawancara dengan pengurus BUMDes Bersama Bangkit Mandiri dan Para Kepala Desa di Kecamatan Nita Kabupaten Sikka. Data laporan keuangan desa - desa di Kecamatan Nita dan data laporan pertanggungjawaban keuangan BUMDes Bersama Bangkit Mandiri dari tahun 2018-2019. Analisis data menggunakan SPSS versi 20.

\section{HASIL DAN PEMBAHASAN}

\subsection{Uji Hipotesis secara Simultan (Uji F)}

Hasil analisis uji hipotesis uji F dengan menggunakan program SPSS 20 : 
Tabel 1. Uji hipotesis simultan (Uji F)

\begin{tabular}{|r|r|r|r|r|r|}
\hline \multicolumn{1}{|l|}{ Model } & \multicolumn{1}{c|}{$\begin{array}{c}\text { Sum of } \\
\text { Squares }\end{array}$} & Df & Mean Square & F & \multicolumn{1}{c|}{ Sig. } \\
\hline $1 \quad$ Regression & $2.928 \mathrm{E} 14$ & 2 & $1.464 \mathrm{E} 14$ & .139 & $.871^{\mathrm{a}}$ \\
Residual & $2.215 \mathrm{E} 16$ & 21 & $1.055 \mathrm{E} 15$ & & \\
Total & $2.245 \mathrm{E} 16$ & 23 & & & \\
\hline
\end{tabular}

Sumber : Data Diolah 2021

Hasil uji statistik berdasarkan perhitungan Anova menunjukkan nilai $F_{\text {hitung }}$ sebesar 0,139 dengan nilai signifikansi sebesar 0.871 Nilai signifikansi 0.871 lebih besar dari tingkat alfa yang digunakan yaitu $5 \%$ atau 0,05 , maka kedua (2) variabel bebas dalam penelitian ini tidak berpengaruh signifikan terhadap Pendapatan Asli Desa $(\mathrm{Y})$. artinya naik-turunnya Pendapatan Asli Desa $(\mathrm{Y})$ tidak ditentukan oleh naik turunnya kedua (2) variabel bebas dalam penelitian ini, yaitu : Penyertaan Modal Desa $\left(X_{1}\right)$ dan Hasil Usaha BUMDes $\left(X_{2}\right)$. Maka dapat disimpulkan bahwa secara bersama-sama kedua (2) variabel bebas yaitu Penyertaan Modal Desa $\left(X_{1}\right)$ dan Hasil Usaha BUMDes $\left(\mathrm{X}_{2}\right)$ tidak berpengaruh signifikan terhadap Pendapatan Asli Desa (Y).

2. Uji Hipotesis secara parsial (Uji t)

Hasil analisis uji hipotesis uji t dengan menggunakan program SPSS 20 :

Tabel 2. Uji hipotesis parsial (Uji t)

\begin{tabular}{|c|c|c|c|c|c|c|c|}
\hline \multirow[b]{2}{*}{ Model } & \multicolumn{2}{|c|}{$\begin{array}{c}\text { Unstandardized } \\
\text { Coefficients }\end{array}$} & \multirow{2}{*}{\begin{tabular}{|c|}
$\begin{array}{c}\text { Standardized } \\
\text { Coefficients }\end{array}$ \\
Beta
\end{tabular}} & \multirow[b]{2}{*}{$\mathrm{t}$} & \multirow[b]{2}{*}{ Sig. } & \multicolumn{2}{|c|}{ Collinearity Statistics } \\
\hline & $\mathrm{B}$ & $\begin{array}{l}\text { Std. } \\
\text { Error }\end{array}$ & & & & Tolerance & VIF \\
\hline 1 (Constant) & $6.828 \mathrm{E} 6$ & $7.880 \mathrm{E} 7$ & & .087 & .932 & & \\
\hline $\begin{array}{l}\text { Penyertaan } \\
\text { Modal }\end{array}$ & -.151 & .712 & -.046 & -.212 & .834 & 1.000 & 1.000 \\
\hline SHU BUMDES & 14.882 & 30.854 & .105 & .482 & .635 & 1.000 & 1.000 \\
\hline
\end{tabular}

Berdasarkan análisis data pada tabel 2 uji hipotesis secara parsial (Uji t) untuk masing-masing variabel bebas terhadap variabel terikatnya adalah sebagai berikut :

1. Variabel Penyertaan Modal Desa $\left(X_{1}\right)$ 
Hasil uji statistik menunjukkan bahwa nilai $t_{\text {hitung }}-.212$ dengan nilai signifikan sebesar 0.843 . Nilai signifikansi lebih besar dari tingkat alpha yang digunakan $5 \%(0,05)$ maka keputusannya adalah menolak hipotesis alternatif $\left(\mathrm{H}_{\mathrm{a}}\right)$ dan menerima hipotesis nol $\left(\mathrm{H}_{0}\right)$, sehingga bisa disimpulkan bahwa secara parsial Variabel penyertaan modal Desa $\left(X_{1}\right)$ tidak berpengaruh signifikan terhadap Variabel Pendapatan Asli Desa (Y). Artinya Jika variabel Penyertaan Modal Desa $\left(X_{1}\right)$ meningkat maka peningkatan variabel penyertaan modal desa ini tidak meningkatkan variabel Pendapatan Asli Desa (Y).

2. Variabel Sisa Hasil Usaha BUMDes $\left(\mathrm{X}_{1}\right)$

Hasil uji statistik menunjukkan bahwa nilai thitung 0.482 dengan nilai signifikan sebesar 0.635 Nilai signifikansi lebih besar dari tingkat alpha yang digunakan $5 \%(0,05)$ maka keputusannya adalah menolak hipotesis alternatif $\left(\mathrm{H}_{\mathrm{a}}\right)$ dan menerima hipotesis nol $\left(\mathrm{H}_{0}\right)$, sehingga bisa disimpulkan bahwa secara parsial Variabel Sisa Hasil Usaha BUMDes $\left(X_{1}\right)$ tidak berpengaruh signifikan terhadap Variabel Pendapatan Asli Desa (Y). Artinya Jika variabel Sisa Hasil Usaha BUMDes $\left(\mathrm{X}_{2}\right)$ meningkat maka peningkatan variabel Sisa Hasil Usaha BUMDes ini tidak meningkatkan variabel Pendapatan Asli Desa (Y).

\subsection{Koefisien Determinasi $\left(R^{2}\right)$}

Hasil analisis dengan menggunakan program SPSS20, didapatkan hasil $\mathrm{R}^{2}$ yang ditunjukkan pada tabel 4.8 . berikut ini :

Tabel 3. Koefisien determinasi $\left(\mathrm{R}^{2}\right)$

\begin{tabular}{|l|l|r|r|c|c|}
\hline $\begin{array}{l}\text { Mod } \\
\mathrm{el}\end{array}$ & $\mathrm{R}$ & $\begin{array}{c}\mathrm{R} \\
\text { Square }\end{array}$ & $\begin{array}{c}\text { Adjusted } \mathrm{R} \\
\text { Square }\end{array}$ & $\begin{array}{c}\text { Std. Error of the } \\
\text { Estimate }\end{array}$ & $\begin{array}{c}\text { Durbin- } \\
\text { Watson }\end{array}$ \\
\hline 1 & $.114^{\mathrm{a}}$ & .013 & -.081 & $3.248 \mathrm{E} 7$ & 1.349 \\
\hline
\end{tabular}

a. Predictors: (Constant), SHU BUMDES, Penyertaan

Modal

b. Dependent Variable: PADES

Sumber : Data Diolah 2021

Berdasarkan hasil analisis data pada tabel 3 , terlihat bahwa nilai koefisien determinasi $\left(R^{2}\right)$ sebesar 0,013 yang berarti bahwa kontribusi dari kedua variabel bebas dalam penelitian ini yang terdiri atas : Penyertaan Modal Desa $\left(X_{1}\right)$ dan Sisa Hasil Usaha BUMDes $\left(X_{2}\right)$ mampu untuk menjelaskan variasi naik turunnya 
Pendapatan Asli Desa (Y) pada seluruh Desa di Kecamatan Nita sebesar 1,3\%. Sedangkan sisanya sebesar $98,7 \%$ dijelaskan oleh variabel-variabel lain yang tidak diikutsertakan dalam model penelitian ini.

\subsection{Pengaruh Penyertaan Modal Desa (X1) terhadap Pendapatan Asli Desa (Y)}

Hasil analisis secara deskriptif menunjukkan bahwa pada variabel Penyertaan Modal Desa nilai terbesar (maksimum) Rp. 50.000.000 (Lima puluh Juta Rupiah) dan nilai terkecil (minimum) sebesar Rp. 25.000.000,- (Dua Puluh Lima Juta Rupiah) Nilai rata-rata (mean) pada Penyertaan Modal Desa sebesar 45833333,33 dengan standar deviation sebesar 9517337,345. Penyertaan Modal Desa terendah berada pada Desa Nita pada tahun 2018. Sedangkan Penyertaan Modal Desa tertinggi berada pada 11 desa yaitu Takaplager, Wuliwutik, Tebuk, Tilang, Lusitada, Bloro, Mahebora, Riit, Ladogahar, Nitakloang, Nirangkliung sebesar Rp. 50.000.000. (Lima Puluh Juta Rupiah). Berdasarkan Undang-Undang Nomor 6 Tahun 2014 pasal 1 ayat (6), menyatakan bahwa Badan Usaha Milik Desa selanjutnya disebut BUMDes merupakan badan usaha yang seluruh atau sebagian besar modalnya dimiliki oleh desa melalui penyertaan langsung yang berasal dari kekayaan desa yang dipisahkan guna mengelola aset, jasa pelayanan, dan usaha lainnya untuk sebesar-besarnya kesejahteraan masyarakat. Penyertaan Modal Desa yang diperoleh BUMDes ini berasal dari 12 desa di Kecamatan Nita yaitu desa Nita,Takaplager, Wuliwutik, Tebuk, Tilang, Lusitada, Bloro, Mahebora, Riit, Ladogahar, Nitakloang, Nirangkliung.

Hasil uji statistik menunjukkan bahwa nilai thitung -.212 dengan nilai signifikan sebesar 0.843 Nilai signifikansi lebih besar dari tingkat alpha yang digunakan $5 \%$ $(0,05)$ maka keputusannya adalah menolak hipotesis alternatif $(\mathrm{Ha})$ dan menerima hipotesis nol (Ho), sehingga bisa disimpulkan bahwa secara parsial Variabel Penyertaan Modal Desa (X1) tidak berpengaruh signifikan terhadap Variabel Pendapatan Asli Desa (Y). Artinya Jika variabel Penyertaan Modal Desa (X1) meningkat maka peningkatan variabel Penyertaan Modal Desa ini tidak secara serentak meningkatkan variabel Pendapatan Asli Desa (Y). Berdasarkan hasil uji statistik ini dapat dijelaskan bahwa penyertaan modal desa ini jika tidak dikelola dengan baik maka tidak dapat meningkatkan Pendapatan Asli Desa.

Hal ini sejalan dengan kondisi yang terjadi saat ini di BUMDes Bersama Bangkit Mandiri yaitu pengelolaan kegiatan usaha yang kurang maksimal. Salah satu kegiatan usaha yang saat ini mengalami kendala adalah kegiatan perguliran dana. Tujuan utama dari kegiatan perguliran dana ini adalah pengembangan usaha ekonomi produktif dan peningkatan kualitas hidup baik individu maupun kelompok menuju kemandirian dan kesejahteraan masyarakat. Sasaran pinjaman dana bergulir yakni seluruh warga Kecamatan Nita dari semua kalangan profesi dan jabatan dengan batas usia maksimal 70 tahun. Modal Perguliran bersumber dari dana UEP/SPP eks PNPM-MPd dan penyertaan modal desa. Kegiatan usaha ini mengalami beberapa kendala seperti kekurangan modal, banyak peminjam dana yang menunggak disebabkan karena ketidakdisiplinan dalam mengelola rencana 
usaha dan lebih banyak dana yang habis untuk dikonsumsi, selain itu masih ada beberapa desa yang sebagian wilayahnya sulit dijangkau karena medan yang sulit, sehingga kegiatan penanganan kredit macet tidak dapat dilaksanakan secara maksimal. Dan juga kondisi ekonomi masyarakat yang kurang stabil dengan adanya pandemi covid 19 ini.

\subsection{Pengaruh Sisa Hasil Usaha BUMDes (X2) terhadap Pendapatan Asli Desa (Y)}

Hasil analisis secara deskriptif menunjukkan Pada variabel Sisa Hasil Usaha BUMDes (X2), nilai terbesar (maksimum) 2529750 dan nilai terkecil (minimum) sebesar 2100000 dengan standar deviation sebesar 219496.496. Dengan nilai ratarata keseluruhan sebesar 2314875.00. Sisa Hasil Usaha BUMDes (X2) terendah berada pada 12 Desa yaitu Nita, Takaplager, Wuliwutik, Tebuk, Tilang, Lusitada, Bloro, Mahebora, Riit, Ladogahar, Nitakloang, Nirangkliung pada tahun 2019. Sedangkan Sisa Hasil Usaha tertinggi berada di tahun 2018.

Hasil uji statistik menunjukkan bahwa nilai thitung 0.482 dengan nilai signifikan sebesar 0.635 Nilai signifikansi lebih besar dari tingkat alpha yang digunakan $5 \%$ $(0,05)$ maka keputusannya adalah menolak hipotesis alternatif $(\mathrm{Ha})$ dan menerima hipotesis nol (Ho), sehingga bisa disimpulkan bahwa secara parsial Variabel Sisa Hasil Usaha BUMDes (X1) tidak berpengaruh signifikan terhadap Variabel Pendapatan Asli Desa (Y). Artinya Jika variabel Sisa Hasil Usaha BUMDes (X2) meningkat maka peningkatan variabel Sisa Hasil Usaha BUMDes ini tidak secara serentak meningkatkan variabel Pendapatan Asli Desa (Y). Berdasarkan hasil uji statistik ini dapat dijelaskan bahwa Sisa Hasil Usaha yang diperoleh BUMDes Bersama "Bangkit Mandiri" cendrung mengalami penurunan di tahun 2019 sebesar Rp. 2.100.000. (Dua Juta Seratus Ribu Rupiah). Penurunan ini akan berdampak pada kontribusi Pendapatan Asli Desa karena BUMDes hanya memberikan kontribusi sebesar $25 \%$ dari sisa hasil usaha yang diperolehnya untuk meningkatkan Pendapatan Asli Desa. Hal ini sejalan dengan kondisi yang terjadi saat ini pada BUMDes Bersama. Jika dilihat dari pendapatan BUMDes Bersama "Bangkit Mandiri"

yang diperoleh dari usaha yang dijalankan cukup besar namun pendapatan yang diperoleh ini jumlahnya sebanding dengan biaya operasional yang dikeluarkan sehingga sisa hasil usaha yang diperoleh BUMDes Bersama relatif kecil. Jadi perlu adanya rasionalisasi biaya-biaya sehingga dapat meningkatkan sisa hasil usaha yang diperoleh untuk meningkatkan Pendapatan Asli Desa.

\subsection{Pengaruh Penyertaan Modal Desa (X1) Dan Sisa Hasil Usaha BUMDes (X2) Terhadap Pendapatan Asli Desa (Y)}

Hasil analisis secara deskriptif menunjukkan pada variabel Pendapatan Asli Desa (Y), nilai terbesar (maksimum) 125627013 dan nilai terkecil (minimum) sebesar 1950000 dengan standar deviation sebesar 31239529.641 Dengan nilai rata-rata keseluruhan sebesar 34363616.17 . Pendapatan Asli Desa (Y) terendah berada pada Desa Nirangkliung pada tahun 2019. Sedangkan Pendapatan Asli 
Desa (Y) tertinggi berada di Desa Tebuk pada tahun 2019. Berdasarkan UndangUndang Nomor 6 Tahun 2014 pasal 1 ayat (6), menyatakan bahwa BUMDes merupakan badan usaha yang seluruh atau sebagian besar modalnya dimiliki oleh desa melalui penyertaan langsung yang berasal dari kekayaan desa yang dipisahkan guna mengelola aset, jasa pelayanan, dan usaha lainnya untuk sebesarbesarnya kesejahteraan masyarakat.

Hasil uji statistik berdasarkan perhitungan Anova menunjukkan nilai Fhitung sebesar 0,139 dengan nilai signifikansi sebesar 0.871 Nilai signifikansi 0.871 lebih besar dari tingkat alfa yang digunakan yaitu $5 \%$ atau 0,05 , maka kedua (2) variabel bebas dalam penelitian ini tidak berpengaruh signifikan terhadap Pendapatan Asli Desa (Y). artinya naik-turunnya Pendapatan Asli Desa (Y) tidak ditentukan oleh naik turunnya kedua (2) variabel bebas dalam penelitian ini, yaitu : Penyertaan Modal Desa (X1) dan Hasil Usaha BUMDes (X2). Dapat disimpulkan bahwa secara bersama-sama kedua (2) variabel bebas yaitu Penyertaan Modal Desa (X1) dan Hasil Usaha BUMDes (X2) tidak berpengaruh signifikan terhadap Pendapatan Asli Desa (Y). Berdasarkan hasil uji statistik ini dapat dijelaskan bahwa sumber Pendapatan Asli Desa tidak hanya diperoleh dari hasil usaha BUMDes dan penyertaan modal desa melainkan dari Hasil kekayaan desa, hasil swadaya dan partisipasi, hasil gotong royong, lain-lain Pendapatan Asli Desa (PADes) yang sah, bantuan dari Pemerintah Kabupaten, bagian dari perolehan pajak dan retribusi daerah, bagian dari dana perimbangan keuangan pusat dan daerah bantuan dari Pemerintah Pusat, Pemerintah Provinsi, Pemerintah Kabupaten dan sumbangan dari pihak ketiga.

Pendapatan Asli Desa (Y) tertinggi berada di Desa Tebuk pada tahun 2019. Pendapatan desa tertinggi ini diperoleh dari tingginya penerimaan Pendapatan Asli Desa dari swadaya pemanfaat rumah layak huni yang diberikan oleh pemerintah.

\section{KESIMPULAN DAN SARAN}

\subsection{Kesimpulan}

Berdasarkan hasil analisis yang telah dibahas, maka kesimpulan dari hasil penelitian ini adalah sebagai berikut:

1. Pada variabel Penyertaan Modal, nilai terbesar (maksimum) Rp. 50.000.000,- (Lima Puluh Juta Rupiah) dan nilai terkecil (minimum) sebesar Rp. 25.000.000,- (Dua Puluh Lima Juta Rupiah) Penyertaan Modal terendah berada pada Desa Nita pada tahun 2018. Sedangkan Penyertaan Modal Desa tertinggi berada pada 11 desa yaitu Takaplager, Wuliwutik, Tebuk, Tilang, Lusitada, Bloro, Mahebora, Riit, Ladogahar, Nitakloang, Nirangkliung. Sisa Hasil Usaha BUMDes (X2) terendah berada pada 12 Desa yaitu Nita, Takaplager, Wuliwutik, Tebuk, Tilang, Lusitada, Bloro, Mahebora, Riit, Ladogahar, Nitakloang, Nirangkliung pada tahun 2019. Sedangkan Sisa Hasil Usaha tertinggi berada di tahun 2018 Pada variabel Pendapatan Asli Desa (Y), nilai terbesar (maksimum) Rp. 125.627.013,- dan nilai terkecil (minimum) sebesar Rp. 1.950.000.- 
Pendapatan Asli Desa ( $Y$ ) terendah berada pada Desa Nirangkliung pada tahun 2019. Sedangkan Pendapatan Asli Desa $(Y)$ tertinggi berada di Desa Tebuk pada tahun 2019.

2. Hasil uji asumsi klasik menunjukan bahwa tidak ditemukan pelanggaran terhadap asumsi klasik yaitu multikolinieritas, normalitas, heteroskedastisitas dan linearitas, maka model regresi linier berganda yang digunakan dalam model penelitian ini dapat digunakan untuk membuat peramalan atau pendugaan terhadap koefisien-koefisien regresi yang dihasilkan dari model

3. Hasil uji statistik $\mathrm{F}$ menunjukkan bahwa secara bersama-sama (simultan) kedua variabel bebas dalam penelitian ini tidak berpengaruh signifikan terhadap Pendapatan Asli Desa (Y)

4. Hasil uji statistik $t$ menunjukkan bahwa secara sendiri-sendiri (parsial) Variabel Penyertaan Modal Desa (X1) tidak berpengaruh signifikan terhadap Variabel Pendapatan Asli Desa (Y).

5. Kontribusi dari kedua variabel bebas dalam penelitian ini yang terdiri atas: Penyertaan Modal Desa (X1) dan Sisa Hasil Usaha BUMDes (X2) mampu untuk menjelaskan variasi naik turunnya Pendapatan Asli Desa $(Y)$ pada seluruh desa di Kecamatan Nita sebesar 1,3\%. Sedangkan sisanya sebesar $98,7 \%$ dijelaskan oleh variabel-variabel lain yang tidak diikutsertakan dalam model penelitian ini.

\subsection{Saran}

Berdasarkan kesimpulan hasil penelitian ini maka dapat disarankan beberapa hal sebagai berikut:

1. Bagi BUMDes Bersama "Bangkit Mandiri" agar perlu tetap mempertahankan penyertaan modal yang sudah dimiliki dengan tetap mengontrol dan mengevaluasi pengelolaan BUMDes Bersama dalam hal ini lebih merasionalisasi biaya-biaya sehingga dapat meningkatkan Sisa Hasil Usaha yang dapat memberikan kontribusi bagi peningkatkan Pendapatan Asli Desa.

2. Bagi desa-desa di Kecamatan Nita, perlu membuat kesepakatan bersama tentang persentase sisa hasil usaha yang nantinya akan dibagikan kepada desa-desa menjadi Pendapatan Asli Desa.

3. Kepada peneliti lain, jika ingin melakukan penelitian serupa, disarankan agar perlu melibatkan variabel lain yang mempengaruhi Pendapatan Asli Desa yang belum diikutsertakan dalam penelitian ini.

\section{DAFTAR PUSTAKA}

Justina Hermin De Fatima, Charles Kapioru \& I Nyoman Sirma. (2020). Evaluasi kinerja keuangan pada badan usaha milik desa (BUMDes) bersama bangkit mandiri di kecamatan nita, kabupaten sikka. Jurnal EXCELLENTIA ( $p$ - 
ISSN:2301-6019) hal (131-138). Volume IX No 2, Desember 2020. Diakses dari https://ejurnal.undana.ac.id

Muryani, (2008). Pembangunan BUMDes dan pemberdayaan pemdes. Bandung : CV Pustaka Setia.

Peraturan Pemerintah Republik Indonesia Nomor 72 Tahun 2005 Badan Usaha Milik Desa. Jakarta.

Peraturan Pemerintah Republik Indonesia Nomor 47 Tahun 2015 Perubahan atas Peraturan Pemerintah Nomor 43 Tahun 2014. Jakarta.

Peraturan Pemerintah Republik Indonesia Nomor 11 Tahun 2021 BUM Desa dan BUM Desa Bersama. Jakarta.

Peraturan Menteri Dalam Negeri Republik Indonesia Nomor 39 Tahun 2010 Badan Usaha Milik Desa. Jakarta.

Peraturan Menteri Dalam Negeri Republik Indonesia Nomor 20 Tahun 2018 Pengelolaan Keuangan Desa. Jakarta.

Peraturan Menteri Desa, Pembangunan Tertinggal dan Transmigrasi Nomor 4 Tahun 2015 Pendirian, Pengurusan dan Pengelolaan dan Pembubaran Badan Usaha Milik Desa. Jakarta.

Undang-Undang Republik Indonesia Nomor 6 Tahun 2014 Desa (Lembaran Negara Republik Indonesia Tahun 2014 Nomor 7, Tambahan Lembaran Negara Republik Indonesia Nomor 5495). Jakarta.

Undang-Undang Republik Indonesia Nomor 32 Tahun 2004 Pemerintah Daerah. Jakarta.

Wiratna Sujarweni. V. (2019). Akuntansi BUMDes. Yogyakarta : Pustaka Baru Pres.

Yabbar, Rahmah \& Ardhi Hamzah. (2015). Tata kelola pemerintahan desa. Surabaya : Penerbit Pustaka. 